\title{
ФИЛОСОФИЯ
}

UDC 321.01

Petar Bojanić

\section{GILLES DELEUZE ON INSTITUTION AND VIOLENCE}

The general idea of the article is to compare Deleuze's theory of the institution, which emerges in the context of various influences of French phenomenology and philosophy of law, with Searle's theory and the latest Anglo-Saxon theories of the institution, and the new institutionalism. Deleuze carelessly differentiates influences and fragments copied or taken over from Hume, Saint-Just, de Sade, Renard, Hauriou, Durkheim, Malinowski and others and in the end completely succeeds in relegating to oblivion his ingenious project from 1953, Instincts and Institutions (Instincts et institutions). The consequences of such writing and theoretical work call into question the status of the theory of the institution and replace it with intuition and recognition that the thematisation of the institution is an impossible task. Thus the author of the article attempts to 'integrate' this impossibility to systematically think or explain the figure of institution into the framework of the great and pioneering work of SaintJust, Hume, Deleuze, Gehlen and Searle.

Deleuze's main contribution to a future imaginary theory of the institution is the concept of a revolutionary institution as the result of reversal and sudden turning, the perverting of something, that happens within the institution. Deleuze uses l'institution révolutionnaire (revolutionary institution) in his texts, certainly completely aware that this phrase has a quite chaotic and vague history during postrevolutionary periods, but also that it is perfectly in the spirit of Saint-Just's intentions. Institutions, free of laws, linking immobilising and moralising actions. Such pure institutions would be models of free actions, anarchic, in perpetual motion, in permanent revolution, in a constant state of immorality.

Revolution is re-institutionalisation (or deinstitutionalisation) which includes different forms of violence. Saint-Just detects two phenomena outside of institutions: terror and corruption. Hume discovers that violence has an advantage over the contract, and that in one way or another gives institutions their dynamic. Thanks to his mixture of these two different registers, Deleuze outlines the transformation of violence into institutions: 1 . Institutionalisation reveals the violence that precedes it and that it interrupts (raw violence or terror), as well as the violence opposed to it (corruption). 2. Violence is minimised in the process of institutionalisation because it is performed by all or the largest possible number of actors. 3. The violence of institutionalisation is violence in the process of conversion (Balibar), it is subsumed into the coercion of rules, into symbolic or institutional pressure. 4. The revolutionary institution supposes that there is no violence that has not been turned into the "body" of the institution, without remainder, and that therefore there is nothing outside of the institution. Refs 19.

Keywords: Theory of the institution, Revolution, revolutionary institution (l'institution révolutionnaire), violence, G. Deleuze.

Petar Bojanić - PhD, Professor, Institute for Philosophy and Social Theory of the Belgrade's University, 45, Kraljice Natalije, Beograd, 11000, Srbija; bojanicp@gmail.com

(c) Санкт-Петербургский государственный университет, 2016 


\section{ЖИЛЬ ДЕЛЕЗ ОБ ИНСТИТУЦИИ И НАСИЛИИ}

\section{Petar Bojanić}

Institute for Philosophy and Social Theory of the Belgrade's University, 45, Kraljice Natalije, Beograd, 11000, Srbija

Основная идея статьи заключается в сравнении теории институтов Делеза, которая возникает в контексте различных влияний французской феноменологии и философии права, с теорией Серла, новейшими англосаксонскими теориями институтов и новым институционализмом. Делез небрежно дифференцирует влияния и фрагменты, заимствованные из Юма, Сен-Жюста, де Сада, Ренара, Ориу, Дюркгейма, Малиновского и других, и в конце концов полностью предает забвению свой гениальный проект 1953 г., представленный в «Инстинктах и институциях». Последствиями такого стиля письма и теоретической работы становится постановка под вопрос статуса теории институтов и замещение последней интуицией или осознанием того, что тематизация институции - это невыполнимая задача. Таким образом, автор статьи осуществляет попытку «интегрировать» эту невозможность систематического осмысления и объяснения фигуры институции в контекст важной и новаторской работы СенЖюста, Юма, Делеза, Гелена и Серла.

Главным вкладом Делеза в будущую воображаемую теорию институтов является понятие революционной институции как результата внезапного поворота, искажения, случившегося внутри институции. Конечно, Делез в своих текстах использует выражение «революционная институция» (l'institution révolutionnaire) безотносительно к истории его довольно хаотического и расплывчатого употребления в постреволюционные эпохи, однако он делает это совершенно в духе намерений Сен-Жюста. Революция порождает институции, свободные от законов, которые связывают и обездвиживают действия посредством их морализации. Такие чистые институции могут стать моделями свободных действий, анархических, находящихся в непрестанном движении, перманентном преобразовании, постоянном состоянии имморальности.

Революция - это реинституализация (или деинституализация), включающая различные формы насилия. Сен-Жюст обнаруживает два явления за пределами институций - террор и коррупцию. Юм доказывает, что насилие имеет преимущество над договором, поскольку в той или иной мере сообщает институтам динамику существования. Благодаря смешению двух этих различающихся регистров Делез демонстрирует трансформацию насилия в революционных институциях. 1. Институализация обнаруживает жестокость или террор как предшествующее ей насилие, которое она прерывает; так же как и насилие, которое этому процессу противостоит (коррупция). 2. В процессе институционализации насилие сводится к минимуму, потому что выполняется всеми или как можно большим числом участников. 3. Насилие институционализации - это насилие в процессе преобразования (Балибар), оно замещается принуждением правил, символическим или институциональным давлением. 4. Революционная институция предполагает, что нет никакого насилия, которое не было бы превращено в «тело» учреждения, без остатка, и поэтому нет ничего за пределами институции. Библиогр. 19 назв.

Ключевые слова: теория институтов, революция, революционный институт (l'institution révolutionnaire), насилие, Ж. Делез.

"Formons la cité!" (Create the City!) [1, p, 1138]

The institution and/or the figure of the 'institution' - already in Deleuze's carelessness in differentiating the singular and plural of this word, as well as in the introduction of the figure of a 'figure' ("L'institution, <...> est un système préfiguré;" "Linstitution, c'est le figuré" $\left.[2, \text { p. } 37,39]^{1}\right)$ - are, without doubt, that which is positive. There is not a single place where Deleuze treats the institution as an obstacle, as something 'petrified' and

1 This "figuré" is translated into English as "the figure" ("The institution is the figure"). G. Deleuze, Empiricism and Subjectivity, tr. C. V. Boundas, New York, Columbia University Press, 1991, p. 49. [2a]. The institution is the figurative, not literal, or the institution marks the figurative (that which exist figures in a different place and becomes something else, something transformed). This figuring elsewhere represents institutionalisation, while the institution is the completion of this process. 
'dead,' and where he calls for the reconstruction, resistance, struggle and tearing down of institutions. Even in the Anti-Oedipus from 1972/3, in which he develops in detail the models of thinking the institution and institutional analysis, completely transforming the 'theory' of the institution from his first texts (more accurately, first fragments), Deleuze says that the great socialist utopias of the $19^{\text {th }}$ century function as "désinvestissement ou une "désinstitution" du champ social actuel," precisely to the benefit of a revolutionary institution of desire itself (au profit d'une institution révolutionnaire du désir lui-même) [3, p.38]. Twenty years earlier, while analyzing Hume and 'l'institution du gouvernement', Deleuze was actually speaking about the correction of sovereignty, the right to resistance, and the legitimacy of revolution (une légitimité de la révolution) [1, p.42]; but even then was the new and ideal institution the only goal. Institutions which 'deinstitutionalize' are not really institutions because they are determined by order and law (les institutions légales et légalisés) [Ibid. P. 74]. That which is institutional ought to probably be that which is revolutionary. Conversely, it seems that the revolutionary should not be found anywhere outside of the institution or the revolution is, in one way of another, la révolution institutionnelle (the revolutionary institution).

Firstly, we are interested in the preference Deleuze has for the phrase l'institution révolutionnaire (revolutionary institution), as opposed to the less original la révolution institutionnelle (institutional revolution) [4, p. 80]. Deleuze uses l'institution révolutionnaire in his texts, certainly completely aware that this phrase has a quite chaotic and vague history during post-revolutionary periods, but also that it is perfectly in the spirit of Saint-Just's intentions. We should investigate whether this phrase best describes Deleuze's imaginary theory of the institution, as well as his engagement with the theory more generally. A much more serious task would consist of comparing Deleuze's theory of the institution, which emerges in the context of various influences of French phenomenology and philosophy of law, with Searle's theory and the latest Anglo-Saxon theories of the institution, and the new institutionalism. The preliminary difficulty, which immediately questions and devalues our commentary, is Deleuze's own refusal to thematise the institution and his own effort, and thus actually answer his own questions from the 1950s: what is it that explains the institution (ce qui explique l'institution) [1, p.38] and "quelles doivent être les institutions parfaites, c'est-à-dire celles qui sopposent à tout contrat, et qui ne supposent qu'un minimum de lois" (what should perfect institutions be like, that is, ones opposed to all agreement, and which suppose a minimum of laws? [4, p. 80]). Instead of exact answers or detailed explanations of his own inspirational or suggestive responses (for example, "Les lois lient les actions; elles les immobilisent, et les moralisent. De pures institutions sans lois seraient par nature des modèles d'actions libres, anarchiques, en mouvement perpétuel, en révolution permanente, en état d'immoralité constante" (Laws link actions; they immobilise and moralise them. Pure institutions, free of laws, would be models of free actions, anarchic, in perpetual motion, in permanent revolution, in a constant state of immorality) [Ibid. p. 79]), Deleuze writes too quickly and carelessly differentiates influences and fragments copied or taken over from Hume, Saint-Just, de Sade, Renard, Hauriou, Durkheim, Malinowski and others. In the end he completely succeeds in relegating to oblivion his ingenious project from 1953, Instincts et institutions (Instincts and Institutions) [5]. Of course the consequences of such writing and theoretical work call into question the status of theory within the framework of institutions and within the actions of revolutionary changes to institutions raising such questions as: who changes institutions, who purifies 
and who sullies them, and, who, if anyone, is the subject of institutionalisation (or deinstitutionalisation?). Also - and this precisely is our problem - Deleuze's carelessness and effectively his abandonment of his own early attempt at conceptualising the institution, could possibly mark his intuition and recognition that the thematisation of the institution is, as of yet, an impossible task. After all, did John Searle not show recently that the theory of institutions has not yet been built and that its development is still in its infancy? $[6, \mathrm{p} .22]^{2}$.

Still, let us attempt to 'integrate' this impossibility to systematically think or explain the institution - the reason for this certainly concerns some 'institutional' or perhaps 'un-institutional' (extra- or anti-institutional) resistance - into the framework of the great and pioneering work of Saint-Just, Hume, Deleuze, Gehlen and Searle. Let us assume, along with Saint-Just, that leaving out systematic thinking about institutions would mean, first of all, the impossibility of founding a republic and building revolutionary institutions. If we wanted to find Gilles Deleuze's main contribution to a future imaginary theory of the institution and starting with his forceful use of the phrase l'institution révolutionnaire, within which are built the efforts of Hume, Saint-Just or de Sade, then it is his insistence that there is a kind of reversal and sudden turning, the perverting of something, carried out by the institution or that happens within the institution or that can be called institutionalisation. This can be labeled as revolutionary. The pure institution or a permanently revolutionary institution - new concepts left to us by Deleuze - abolish, for example, corruption within the republic ${ }^{3}$ or they reappropriate non-institutionalised spaces within the republic or transform, or force the transformation of anything which is limited or in some way particular ${ }^{4}$. Opposed to that, the impotence of systematic thinking or the impotence of institutionalisation (this is the process that 'institutionalises' that which confronts it or resists it) paradoxically shows that we are still in a truly pre-revolutionary and therefore pre-institutional time, in which Saint-Just himself lived. Our eternal contemporary, Saint-Just detects two phenomena or two entities outside of institutions, and which only the (revolutionary) institution can realise: terror and corruption. In fact, we can confirm that these two forms of violence (let us be on guard about the as of yet completely uncharted relation between corruption and violence) still today oppose the institution and represent its main temptation. It seems that it was Deleuze who had already discovered in Hume - although this too is never fully thematised - the great beginning of the story of violence as the source and origin of the institution and order. Well before Hegel and Engels, and much later Benjamin (Balibar has recently published a long text about violence which gives important explanations of the process of 'conversion' and 'un-conversion'

\footnotetext{
${ }^{2}$ Hugh Heclo showed this problem analysing twenty-one definitions of the institutions (in fact there are many more) which are currently used. Cf. [7, p. 48-51].

3 "La terreur peut nous débarrasser de la monarchie et de l'aristocratie; mais qui nous délivrera de la corruption? Des institutions. On ne s'en doute pas; on croit avoir tout fait quand on a une machine à gouvernement..." (Terror can rid us of the monarchy and the aristocracy; but who will save us from corruption? Institutions. Regarding that, there is no doubt; we think we have done everything when we have a governing machine...") [5, p. 35; 1, p. 1135$]$.

4 Deleuze's engagement is different from Merleau-Ponty's and his reconstruction of Husserl's Stiftung and reinstutionalisation. For Merleau-Ponty the revolution is something already set in the fondation, in the first violence. The revolution is "réinstitution, aboutissant à renversement d'institution précédente" (the reinstituionalisation, the achievement of the overturn of the previous institution). Cf., [8, p.42].
} 
of violence into an institution [9, p. 48, 66, etc.]), Hume discovers that violence has an advantage over the contract, and that in one way or another gives institutions their dynamic.

\section{Deleuze's Hume and Deleuze's Saint-Just}

It is entirely possible to reconstruct Deleuze's effort, and at the same time his difficulty in explaining his intention, based on the sixty-six fragments from his collection Instincts et institutions 5 . His "Introduction" ${ }^{5}$ to the collection, and a few pages and fragments he wrote or delivered during his life (known to us thus far), allow only the recognition of the advantage Deleuze gives certain authors: to his first book, Deleuze contributes two fragments from Hume, which he will then analyse elsewhere, and the famous paragraphs by Saint-Just about "institutions, moeurs et loi" (institutions, mores and law); further, a few fragments about institutions and organisation (Buytendijk, Halbwachs); from Hauriou Deleuze will take the differentiation between institution and personification, from Renard the difference between contrat and institution (contract and institution), which he will then wrongly attribute to Hume, from Levi-Strauss and Frazer he will take the relationship between instinct and tendance (tendency) on the one hand and institution on the other, and from Durkheim he will learn that enforcement is the main characteristic of the institution, from Malinowski, again, Deleuze takes the link between the institution and the means, between charte (charter) and institution, [5, p. 4-5] $]^{7}$ etc.). It is also possible to show some oversights and dilemmas, that is show what he had not done and what remains to be done. For example, it is necessary to come back to that place in the Introduction where Deleuze asks about the institution of the state, to which no tendency corresponds ("auxquelles ne correspond nulle tendance"). What at all does the state as an institution satisfy in us? Or what is the position of the state in the order of institutions (for Searle, the state is the ultimate institutional structure, while Renard recognises a federal state which he terms l'institution des institutions)? We ought always to reread that sudden conclusion of Deleuze's in Empirisme et subjectivité, or rather the page that follows "ce qui explique

\footnotetext{
${ }^{5}$ Deleuze collected portions of various texts about institution and intuition. The book contains writings by Malinowski, Alain, Hume, Levi-Strauss, Kant, Frazer, Freud, Eliade, Plekhanov, Bergson, Goldstein, Saint-Just, Renard, Bachofen, Comte, Marx and many others. It appears that Deleuze translated only four fragments from English (for example Malinowski and Frazer), while most fragments are taken from already existing translations into French. The early texts and intentions of Deleuze were written about inspiringly by Guillaume Sibertin-Blanc in his doctoral thesis Politique et Clinique [Political and Clinical], defended in 2006 (p. 48-74, etc.).

${ }^{6}$ The short Introduction (p. viii-xi) was republished in the magazine Philosophie (N 65, 2000, p. 23-26) and in the book L'île déserte [Desert Island] (1953-1974) [10, p. 25-27].

7 The sentence "L'institution se présente toujours comme un système organisé de moyens" from Deleuze's introduction is in fact a sentence from Malinowski, "The institution as the organised means of realising the values...”, which Deleuze did not translate [11, p. 157]. The two fragments of Malinowski found at the very beginning of Deleuze's book explain the socio-psychological moment in Deleuze's explanations of the institution. Social institutions exist to 'answer' or to 'meet' psychological needs, and every institution possesses personnel, a charter, a set of norms, activities, apparatus, functions, etc. Deleuze later uses the term 'charter' (a term Deleuze could have also found in Renard's book La philosophie de l'institution from 1939), which gives universality of structure to an institution, in a book dedicated to Foucault: "Une institution comporte ellemême des énoncés, par exemple une constitution, une charte, des contrats, des inscriptions et enregistrements" (An institution includes its own utterances, for example a constitution, a charter, agreements, inscriptions and records) [12, p. 19].
} 
l'institution, ce n'est pas la tendance, mais la réflection de la tendance dans l'imagination" (the institution is not explained by the tendency, but by the reflection of the tendency in the imagination) [1, p.38]. Where does imagination come from? Still, it seems most important for us now, as was mentioned, to construct a modest theory about Deleuze's interruption of work on the theory of the institution in order to, in any sense, explain his discovery or sketch of a 'new' interpretation of the institution. Of course, this 'interruption' means that Deleuze, without huge complications, is able to transfer and make use of his early research in his later 'theories of institutional analysis', and, we are assuming, that Deleuze is able to somehow grasp what 'the essence' of the institution is, while at the same time show the difficulties and limits of the thematisation of the institution. The results of his efforts surrounding the institution from the fifties, then, can be found 'in effect' later, primarily in his work in the eighties. We mean above all the model of argumentation, or the way of advancement of thought or succession of terms in Deleuze, which we could label as 'institutionalisation' or 'reversal' (renversement). Deleuze could have found the origin of this method in those sixty-six fragments about the institution or, more precisely, thanks to a mixture of influences of Hume and Saint-Just, but also through conscious or unconscious opposition to all classical forms of dialectic and Hobbes' understanding of the institution. The lack of Hobbes in Deleuze's choice of fragments means the rejection of a specific model of the use of the verb 'to institute,' which Hume himself neglects and relegates to a secondary importance. In Hobbes, 'to institute' means to decide, to begin something with determination. It is the decisive subjective act of starting something (out of nothing), which is actually opposite (but analogous) to the creation of nature and is an act committed by Hobbes' active subject ${ }^{8}$. The uncertainty of the subject, but also the sudden appearance of the object of institutionalisation (institué) (is this a way to explain the importance of Hume for Deleuze and us all?) is achieved based on at least three simultaneous and complementary operations. Neglecting the sovereign act of the founding of a social form is conducted through the appearance of a contract (between some two, or two sides that come to an agreement as opposed to a single, sovereign decision), then by the introduction of multiple subjects or a group (a collective) whose members together 'accomplish' the process of institutionalisation or for example, 'legalisation' of their own property, and finally, the discovery that the decision or institutionalisation is neither perfect nor complete. Why institutionalisation or the institution is not perfect and hence not sovereign, is shown by Hume explicitly in two places which Deleuze knows very well, but never analyses. Here are the quotes now, in English, immediately pointing to the important problem of translation or reversal of 'the institution' from Latin or English into French or our own language:

Time and custom give authority to all forms of government, and all successions of princes; and that power, which at first was founded only on injustice and violence, becomes in time legal and obligatory $[16]^{9}$.

${ }^{8}$ Hobbes' use of 'to institute' harkens back to medieval meaning of the term 'institutio' (an order or command). It is interesting that Pufendorf in De iure naturali et gentium uses the word impositionis (imposition) in this sense, which the French translator, Barbeyrac translates as l'institution. Since he cannot find an equivalent in French for imposition, he is forced to defend his solution. " $<\ldots>$ we use institution most often for that which is invented and established, as opposed to coming from nature. $<\ldots>$ our author (Pufendorf) wants to say when he posits that in fact moral things are such by imposition, and not in themselves or by nature." Cf. [14, p. 175-176].

${ }^{9}$ Cf. [16, book III, part 2, 10 "Of the objects of allegiance"]. 
Time, by degrees, removes all these difficulties, and accustoms the nation to regard, as their lawful or native princes, that family, which, at first, they considered as usurpers or foreign conquerors. In order to found this opinion, they have no recourse to any notion of voluntary consent or promise, which, they know, never was, in this case, either expected or demanded. The original establishment was formed by violence, and submitted to from necessity. The subsequent administration is also supported by power, and acquiesced in by the people, not as a matter of choice, but of obligation ${ }^{10}$.

Probably no one prior to Hume says, and repeats, so clearly that violence ('violence and injustice') is at the beginning, and that for Hobbes 'to institute' or for Hume 'to establish' are concepts and terms completely imbued with violence. However trivial this demystification of the 'sovereign' and 'institutional act' seems today, Hume would forever change the accent from the institution as such or the sovereign who founds the institution, to the process itself of institutionalisation (a verb) and the object (that which is being institutionalised, institué, and then that which can be institutionalised). Of course, Hume's intervention would be a preamble to any further, no less important, finesse and nuance in conceptualising the institution: various theories of 'counter-institutions', which can be followed from Saint-Simon (Hume's contemporary) to Durkheim and Derrida; complex theories about the existence of institutions (and customs) not established by norms or the theory of the origin of social institutions in conditions in which there is no common will for their establishment (for example, the institutions of money, language, the market, law, etc.) (Carl Menger).

What is it then, that Hume does? How was the perspective or the accent changed from 'the institution' to 'the institutionalised' (institué)? How does Deleuze read Hume, and then how does he combine this question with, above all, Saint-Just? The answer to these questions should show the justification of our insistence that Deleuze uses and transforms Hume's intervention or discovery of the drama of 'institutionalisation' (whereby something forcibly changes from one thing to another), into the main mode of execution of his argument and his analysis. In other words, it should become clear how Deleuze's gerund from the Introduction, where institutions "transforment la tendance elle-mêmes en introduisant dans un milieu nouveau" [5, p.24] (themselves transform the tendency by introducing it to a new context), and force and oppress ${ }^{11}$ at the same time that they satisfy (a desire), turns into the passive voice ("l'espace institué par l'appareil d'Etat" (space instituted by the state apparatus) [3, p. 592]), and then into practice, into the discovery of a substantive derived from the verb 'to institute' - institutionalisation, statification. Deleuze formulates all this in the following way:

Les institutions ne sont pas des sources ou des essences, et elles n'ont ni essence ni intériorité. Ce sont des pratiques, des mécanismes opératoires qui n'expliquent pas le pouvoir, puisqu'lles en supposent les rapports et se contentent de les "fixer", sous une fonction reproductrice et non productrice. Il n'y a pas d'Etat, mais seulement une étatisation, et de même pour les autres cas [12, p. 82].

(Institutions are not sources or essences, and they have neither essences nor interiorities. They are practices, operating mechanisms that do not explain power, because they assume these relations and content themselves with 'affixing' them, as part of their function to reproduce and to produce. There is no State, but only a statification, and the same as in all other cases).

\footnotetext{
${ }^{10}$ Cf. [17].

${ }^{11}$ Cf. [2, p. 37].
} 
Even though Deleuze's and Foucault's common insights into institutions incorporate Saint-Just's and de Sade's visions of new, future institutions ${ }^{12}$, in which dominates " $u n$ modèle dynamique d'action, de pouvoir et de puissance" (a dynamic model of action, power and force) [4, p.78], they could not exist without Hume. Hume, but also Saint-Just, both constructs the institution as big, common action that unfolds in an unfinished time. The instance of time is precisely the key difference between the institution and a contract, about which Deleuze writes inspiringly in a book in which he does not at all mention Hume.

On connâit la distinction juridique entre le contrat et l'institution: celui-là en principe suppose la volonté des contractants, définit entre eux un système de droits et de devoirs, n'est pas opposable aux tiers et vaut pour une durée limitée; celle-ci tend à définir un statut de longue durée, involontaire et incessible, constitutif d'un pouvoir, d'une puissance, dont l'effet est opposable aux tiers [Ibid] ${ }^{13}$.

(We are aware of the legal difference between a contract and the institution: the first in principle assumes the willing participation of the parties, defined between them as a system of rights and obligations, not opposable to a third party, and lasts a definite duration; the latter tends to define position in the long term, involuntary and inaccessible, constituted by power, a force, and refers to other parties).

A multitude makes institutions or the people makes an institution (l'institution des peuples [1, p. 1091]), and this work happens before everyone's eyes, as a public thing, concerning everyone, like the republic. In both fragments quoted here, Hume shows that time, before the eyes of a multitude, gradually hides (or reveals) what is at the root of power and establishments. Over time, again gradually, the process of institutionalisation occurs and the reversal of violence and injustice into stable forms takes place; forms which bind not only those who participate in the original violence and injustice, but also all those who will in due course become members of a given community ('other parties', tiers). Hume thus recognises two processes: firstly, the silhouette of violence and injustice within the power of institutions, underneath the institutions, that is the former process of 'founding' (was founded only on injustice and violence) and 'forming' (was formed by violence), but also at the same time, claims that several factors will contribute to the fading of this silhouette, and its eventual 'institutionalisation.' And although it seems that the key factors in the realisation of this second process are time (its passage) and the common engagement of the multitude - there is no institution without the pressed, controlled, obligated, forced, bound ${ }^{14}$, etc. - it is necessary to add that the process of 'institutionalisation' is a priori expansive, and never partial. Meaning, everyone must be engaged, and every form of violence abolished. There is nothing that is outside of the institution. For violence that destroys parts of

${ }^{12}$ Cf. [18, p. 353-354]. “Trois principaux moyens de codage: la loi, le codage et l'institution. <...>Et puis il y a une troisième sorte de livres, le livre politique, de préférence révolutionnaire, qui se présente comme un livre d'institutions, soit d'institutions présentes, soit d'institutions à venir". (Three principal means of coding: law, coding and the institution. $<\ldots>$ And then there is a third kind of book, the political, preferred by revolutionaries, which presents itself as a book of institutions, whether present or future).

${ }^{13}$ This slightly changed interpretation of Renard's difference between the institution and the contract is 'pressed' by Deleuze's early and late attempts to construct an implicitly Humean differentiation between contract and institution. Cf. [2, p. 35-37; 19, p. 232].

${ }_{14}$ "Si un homme na point d'amis, il est banni;" (If a man has no friends, he is banished). "Celui qui dit qu'il ne croit pas à l'amitié est banni;" (He who says that he does not believe in friendship is banished). "Si un homme commet un crime, ses amis sont bannis." (If a man commits a crime, his friends are banished) [Ibid., p. 1102-1103]. 
the community and forcibly occupies objects and territory, for violence that comes from simple egoism and limitation to stop, Hume thinks that it is necessary to stabilise the given establishment together, and that the result of this process will be power, i.e. the institution as manifestation of power. Two words, establishment and institution, that Hume differentiates, a difference that Deleuze or French translators do not detect, could explain, paradoxically, everything we owe to Saint-Just ${ }^{15}$. Terror and corruption, the two 'forms' of violence that are outside the institution, or have yet to be institutionalised, according to Saint-Just, are in the exact place of these analyses of Hume's, and in place of prepositions under (establishment) and outside (institution). When institutions become damaged or perverted (pervert) ${ }^{16}$, when people and human nature sully them, when they become occupied by perversion (another word Hume uses) and corruption, it is then possible to recognise that at the origin of these establishments lies that same violence (killing, robbing, etc.) or terror. Violence and terror become visible elements of order and the institution (for example, the institution of property, which greatly interests Hume - Deleuze first of all carefully reads and analyzes Hume's analyses of property and obedience from A Treatise of Human Nature and from An Enquiry Concerning the Principles of Morals) when they seem insufficient to prevent the opposition to the process of institutionalization (reversal or revolution).

\section{Of reversal (renversement)}

Let us assume that the 'deformation' or 'perversion' of which Hume speaks, and for which people or a corruptible human nature are responsible, is what marks the failure of reversal and a misguided revolution. There is no revolutionary institution because not everyone is engaged in a process of grouping or cooperation, there are still those who are passive, who are in the way, to whom Saint-Just often calls and seriously explains the importance of their engagement. The idea that someone is missing, and is beyond the control and pressure of the group, the idea that there is no group or collective (institutional) responsibility, is truly an important condition for violence to forever be institutionalized, that is to be erased and transformed into something else. This dynamic process that presumes that there is no exception, no special case (no state of emergency), and that all work together and are in toto engaged in the creation and formation of the city, suits Hume's and Saint-Just's use of the word institution. When Hume uses two different words, institution and establishment, which imply that the violence has stopped his intention, may have been to construct two different moments or steps in the undertaking of legalization of ownership acquired by way of violence. The first step, Hume calls it establishment - implies the building of power (the change of force or violence into power) through stabilising the given state immediately after the various crimes took place. This step, simultaneously the birth of 'the institution of property' (this is Hume's term) or in another context, 'the institution of social property', becomes binding for all social actors. The factor of time, especially emphasised by Hume, refers to the gradual broadening of the process of insti-

${ }^{15}$ In the most important place where he thematizes the institution in Empirisme et subjectivité, Deleuze first drops an important portion of the section from Hume's An Enquiry Concerning the Principles of Morals, and then quotes Hume from The Treatise of Human Nature (page 620 in the French translation): "Bien que l'institution de la règle sur la stabilité de la possession soit non seulement utile..." (p. 37), while the original reads: "Tho' the establishment of the rule..."

${ }^{16}$ Cf. [16, book III, part 2, 9 "Of the measures of allegiance"]. 
tutionalisation to all, the inclusion and binding of all. Let us look at how Saint-Just and Deleuze understand this process and how they formulate it:

Il faut substituer, par les institutions, la force et la justice inflexible des lois à l'influence personnelle. Alors la révolution est affermie: il n'y a plus de jalousies, ni de factions: il n'y a plus de prétentions ni de calomnies.

Les institutions ont pour objet détablir de fait toutes les garanties sociales et individuelles, pour éviter les dissensions et les violences; de substituer l'ascendant des mours à l'ascendant des hommes [1, 1091].

(Institutions ought to substitute power and inflexible justice of laws subject to personal influence. Only then is the revolution consolidated: there are no more jealousies or factions, nor pretensions or libel.

The goal of institutions is to establish in fact all social and individual guarantees to avoid dissent and violence; to substitute the ascendancy of traditions with the ascendancy of man).

Institutions ought to stand in for, to replace something that precedes them (violence, force and different forms that divide people), for the revolution only then to be actualised or fully executed. The erasure of violence and force through institutions caps the revolution and is revolutionary. At the same time, institutions prevent conflict and violence, which are obviously a consequence of an insufficiently actualised 'replacement.' Saint-Just obviously predicts that this process of replacement of violence with institutions occurs within a certain timeframe, and whereby the dynamics and activity within institutions can be explained.

Deleuze uses the same verb as Saint-Just:

Le monde moral affirme sa réalité quand la contradiction se dissipe effectivement, quand la conversation est possible et se substitue à la violence, quand la propriété se substitue à l'avidité (...) Etre en société, c'est d'abord substituer la conversation possible à la violence $[2$, p. 27, 29].

(A moral world affirms its reality when the contradiction is effectively resolved, when conversation is possible and takes the place of violence, when property is replaced with greed $\langle\ldots\rangle$ to be in society is first of all to substitute violence for a possible conversation).

In the book about Hume, Deleuze channels Saint-Just. Thanks to his mixture of two different registers and two different commentaries, it is clear that Deleuze announces yet again (although neither explicitly nor without reserve) 'the subject' of institutionalization. This subject, however, is completely different from that of Hobbes. To be part of society or to be together presupposes 'the substitution' of violence into revolutionary institutions. All we can do now is perhaps only tentatively list the conditions and the framework of this task or charge that remains untouched from Saint-Just to Deleuze. It seems that this sketch of turning violence into institutions could only be successful if it could position exactly the different forms of violence within this revolutionary theatre:

a) The substitution is violent or the institutionalisation is violent if it does not only consist of one act that births or founds a new order or establishment, but rather of many permanent actions and acts that become more complicated over time. Institutionalisation reveals the violence that precedes it and which it interrupts (raw violence or terror), and violence which is opposed to it (corruption).

b) Three violences that are different in form and strength determine the number of actors who perform it. Violence is minimised in the process of institutionalisation because it is performed by all or the largest possible number of actors. 
c) Violence of institutionalisation is violence in the process of conversion (Balibar). Violence of founding (fondation) and violence of terror is transformed (translated, transposed, reversed, substituted) into the coercion of rules, into the symbolic or institutional coercion or pressure.

d) The revolutionary institution supposes that there is no violence that has not been turned into the 'body' of the institution, without remainder, and that therefore there is nothing outside of the institution.

\section{References}

1. A.-L. de Saint-Just. Institutions républicaines. Euvres complètes. Paris, Gallimard, 2004.

2. Deleuze G. Empirisme et subjectivité. Paris, PUF, 1953. G. Deleuze. Empiricism and Subjectivity. Tr. C. V. Boundas. New York, Columbia University Press, 1991.

3. Deleuze G. Capitalisme et schizophrénie. L’Anti-CEdipe. Paris, Minuit, 1972/1973.

4. Deleuze G. Présentation de Sacher-Masoch. Le Froid et le Cruel. Paris, Minuit, 1967.

5. Deleuze G. Instincts et institutions (textes choisis et présentés par G. Deleuze). Paris, Hachette, 1953.

6. Searle J. "What is an institution?" Journal of Institutional Economics, 2005, yr. I, no. 1.

7. Heclo H. On Thinking Institutionally. Boulder-London, Paradigm Publishers, 2008.

8. Merleau-Ponty M. L'institution. La passivité. Notes de cours au Collège de France (1954-1955). Paris, Berlin, 2003.

9. Balibar E. Violence et civilité. Paris, Galilée, 2010.

10. Deleuze G. Introduction. L'̂̂le déserte et autres textes (1953-1974). Édition préparée par David Lapoujade. Paris, Minuit, 2002.

11. Malinowski B. Freedom and Civilization. London, Allan Wigate, 1947.

12. Deleuze G. Foucault, Paris, Minuit, 1986.

13. Rangeon F. "Approche de l'institution dans la pensée de Hobbes". L'institution. Paris, PUF, 1981.

14. Orestano R. "Institution.' Barbeyrac e l'anagrafe di un signifato". Quaderni Fiorentini, 1982, yr. 1, no. $11-12$.

15. Deleuze G. “Trois problèmes de groupe”. Lî̀le déserte et autres textes (1953-1974). Édition préparée par David Lapoujade. Paris, Minuit, 2002.

16. Hume D. A Treatise of Human Nature. Reprinted from the Original Edition in three volumes and edited, with an analytical index, by L. A. Selby, Bigge, M. A. Oxford: Clarendon Press, 1896.

17. Hume D. "Of the Original Contract" (1752). Essays Moral, Political, and Literary. Editor \& Trans. Eugene F. Miller. Indianapolis, 1987.

18. Deleuze G. "Pensée nomade". Lîle déserte et autres textes (1953-1974). Édition préparée par David Lapoujade. Paris, Minuit, 2002.

19. Deleuze G. "Hume" (1972). L'̂̀le déserte et autres textes (1953-1974). Édition préparée par David Lapoujade. Paris, Minuit, 2002.

For citation: Petar Bojanić. Gilles Deleuze on Institution and Violence. Vestnik of Saint-Petersburg University. Ser. 17. Philosophy. Conflict. Cultural. Religious, 2016, issue 2, pp. 4-14. DOI: 10.21638/11701/ spbu17.2016.201 